\title{
2006-2154: EFFECTIVE TEACHING AND LEARNING: PREDICTING STUDENT LEARNING AND SUCCESS FOR NON-TRADITIONAL STUDENTS IN CONTEXT OF FACULTY AND STUDENT TRAITS
}

\author{
Ahmed Khan, DeVry University-Addison \\ Dr. Ahmed S. Khan is a senior Professor in the EET dept. at DeVry University, Addison, Illinois. \\ He received his M.Sc (applied physics) from University of Karachi, an MSEE from Michigan \\ Technological University, and an MBA from Keller Graduate School of Management. He \\ received his Ph.D. from Colorado State University. His research interests are in the areas of Fiber \\ Optics Communications, faculty development, and outcomes assessment, and, Internet and \\ distance education. He is author of "The Telecommunications Fact Book" and co-author of \\ "Technology and Society: Crossroads to the 21st Century" and "Technology and Society: A \\ Bridge to the 21 st Century." He is a member of IEEE, ASEE, ASQ, and LIA.
}

\section{Shawn Schumacher, DeVry University}

Dr. Shawn Schumacher is a senior Professor of English and Humanities at DeVry University, Addison, Illinois. He received his MA from Governors State University in English Literature and his Ph.D. from Colorado State University in Educational Leadership. His research interests include curriculum and instruction, teacher education, faculty development, and leadership. He has written various papers and has spoken at several education and literary national conventions and conferences. He is a member of ASCD, NCTE, MLA, and AERA.

\section{Lynn Burks, DeVry University}

Dr. Lynn Marie Burks is a Professor in the Business department at DeVry University, Addison, Illinois. Ms. Burks received her BS in Economics, BS in Business, and MA in Economics from Eastern Illinois University, and her Ph.D. from Colorado State University. Ms. Burks came to DeVry University from the National Opinion Research Center at the University of Chicago with a background in finance and administration of survey research. Her research focus is student persistence in higher education where she proposed and tested a longitudinal theoretical model of student persistence. Ms. Burks' expertise in this area is of particular importance due to the lack of theoretical and quantitative data representing nontraditional students and institutions. Dr. Burks also holds a variety of leadership positions within her community serving on the board member for the Yorkville Community School District \#115 as well as several other volunteer organizations that serve families and children in her community. She is a member of AEA, ASCD, BHA, EDRed, and ISBE. 


\title{
Effective Teaching and Learning: Predicting Student Learning and Success for Nontraditional Students in Context of Faculty and Student Traits
}

\begin{abstract}
Changing demographics suggest that much of the growth in higher education will come from diverse students consuming higher education in nontraditional formats. This paper present the findings of three studies conducted to determine various factors that contribute to effective teaching and learning for non-traditional students at a for-profit institution of higher learning.
\end{abstract}

The first study explores the relationships between students' perceptions of the importance of three faculty dimensions --- technical currency, teaching techniques, and commitment to student success --- to their learning/success, expressed in terms of self-reported technical competencies and GPA in a technology-based baccalaureate electronics engineering technology (EET) program at a teaching university. The sample $(\mathrm{N}=225)$ was composed of seniors of the BSEET program (Fall 2003) from 13 geographically diverse campuses of a teaching university. More than $75 \%$ of the EET seniors agreed that the constructs of faculty technical currency, teaching techniques, and commitment to student success, are important to their learning/success.

The second study deals with the conditions relating to faculty assimilation, teacher preparation, and teacher effectiveness at a for-profit institution of higher education. The study examines faculty assimilation, teaching practices, and teaching preparation at the Chicago campus of DeVry University, a for-profit, non-traditional university. Findings of the study are used to develop a model for teaching preparation and practice at forprofit, non-traditional universities.

The third study deals with developing and testing a longitudinal model synthesized from the literature to (a) investigate the associations on persistence for nontraditional students attending nontraditional institutions, (b) assist staff, faculty, and administrators implement high quality intervention strategies, and (c) refocus institutional resources toward enhancing student persistence. Data were collected in a three-step process over a 5 -year period. Results yielded significant differences between students who persisted to their second year or not and those who graduated or not within 5 years. Further analyses indicated that satisfaction significantly decreased on every construct in the theoretical model as students moved from their first to second year. Prior research studying commuter institutions showed background characteristics of the student as the most important associations on short-term outcomes and persistence decisions. Results of this study indicated the opposite; institutional and interactional variables were associated with persistence decisions for commuter students. 


\section{Study-I: STUDENTS' PERCEPTIONS OF THE IMPORTANCE OF THE FACULTY DIMENSIONS OF TECHNICAL CURRENCY, TEACHING TECHNIQUES, AND COMMITMENT TO STUDENT SUCCESS FOR THEIR LEARNING/ SUCCESS}

\section{Introduction}

The objective of this study was to explore the relationships between students' perceptions of the importance of three faculty dimensions --- technical currency, teaching techniques, and commitment to student success --- to their learning/success, expressed in terms of self-reported technical competencies and GPA in a technology-based baccalaureate electronics engineering technology (EET) program at a teaching university.

The accreditation bodies such as Accreditation Board for Engineering and Technology (ABET) place high emphasis on the technical currency of faculty, and require institutions to provide opportunities for faculty to keep abreast of the pace of technological advances. ABET's 2003-2004 criteria for accrediting engineering technology programs state [1]:

In engineering technology programs, technical currency is important and must be assured by such means as a competent and inquisitive faculty, an active industrial advisory committee, and an adequately funded budget which encourages continuing faculty development, and a modern library collection with an adequately funded program for continuous renewal. Positive procedures must be established and closely monitored to safeguard against technical obsolescence. (p. 5)

Accreditation bodies have placed high emphasis on technical currency of faculty in the technology based programs, but the subject has received little attention in the literature. Further, no studies have been conducted to investigate the associations between the faculty dimensions of faculty technical currency, faculty teaching techniques, and faculty commitment to student success, and self-reported student learning and success. Faculty professional development activities and technical currency play an important role in promoting student learning and success. Therefore, an investigation is warranted to explore the relationship between student learning/success with these faculty constructs.

\section{Purpose of the Study}

The purpose of this research project was to explore the relationship between students' perceptions of the importance of three faculty dimensions - technical currency, teaching techniques, and commitment to student success - and their self-reported learning and success. The research project answers the following question:

How do students perceive the importance of three faculty dimensions - technical currency, teaching techniques, and commitment to student success, for their learning and success? (Are means high or low?) 
Table I

Description of Variables

\section{Variable Type}

\section{Independent Variables}

Student perceptions of the importance of:

1. Faculty Technical currency (FTC)

2. Faculty Teaching Techniques (FTT)

3. Faculty Commitment to Student Success (FCSS)

\section{Variable Description}

Faculty technical currency construct is expressed in

terms of the following;

- Technical competency/technological knowledge/skills in the subject matter (up-todate technical knowledge)

- Computer hardware skills

- Computer software skills

- Knowledge of new and emerging technologies

- Publications of technical papers and textbooks

- Participation in technical seminars, workshops $\&$ conferences, and professional organization activities.

Faculty teaching techniques construct is expressed in terms of following factors:

- Lectures

- Use of a variety of technological teaching tools

- Use of PowerPoint

- Use of a variety of teaching strategies

- Use of group presentations

- Coordinating lab work with theoretical concepts covered in lecture

- $\quad$ Organizing and preparing of class and lab activities

- Use of individual lab projects

- Providing timely feedback on class and lab projects

Faculty commitment to student success construct is represented by:

- Dedication to students

- Requiring high expectations

- Being approachable 
- Encouraging student accomplishments

- Concern for student success

\section{Dependent Variables}

Students' perception of their learning / success in terms of:

\section{GPA}

2. Self-reported technical competency (SRTC1) [Critical Thinking]

3. Self-reported technical competency (SRTC2) [Job Preparation]

4. Self-reported technical competency (SRTC3) [Construction of a Prototype]
Student learning / success measured is terms of:

- GPA

- $\quad$ Self-reported technical competency (SRTC) [in terms of analytical and critical thinking, knowledge of EET, and design and implementation of a system]

- Given a technical challenge, a student can analyze a problem by thinking critically (SRTC1 [Critical Thinking])

- Student has confidence in his/her technical knowledge to be successful as an electronics engineering technology (EET) job (SRTC2) [Job Preparation]

- Given a technical problem or specification for a system design, a student can propose a solution by designing the necessary subsystem/circuits and by constructing a prototype of the system (SRTC3) [Construction of a prototype]

- Number of job offers

- Starting salary offer

- Professional/honor society membership 


\section{Description of Sample and Sampling Design}

\section{Sampling}

Considering the time and cost limitations, a convenience sampling approach was employed. Figure 2 illustrates the sampling scheme.

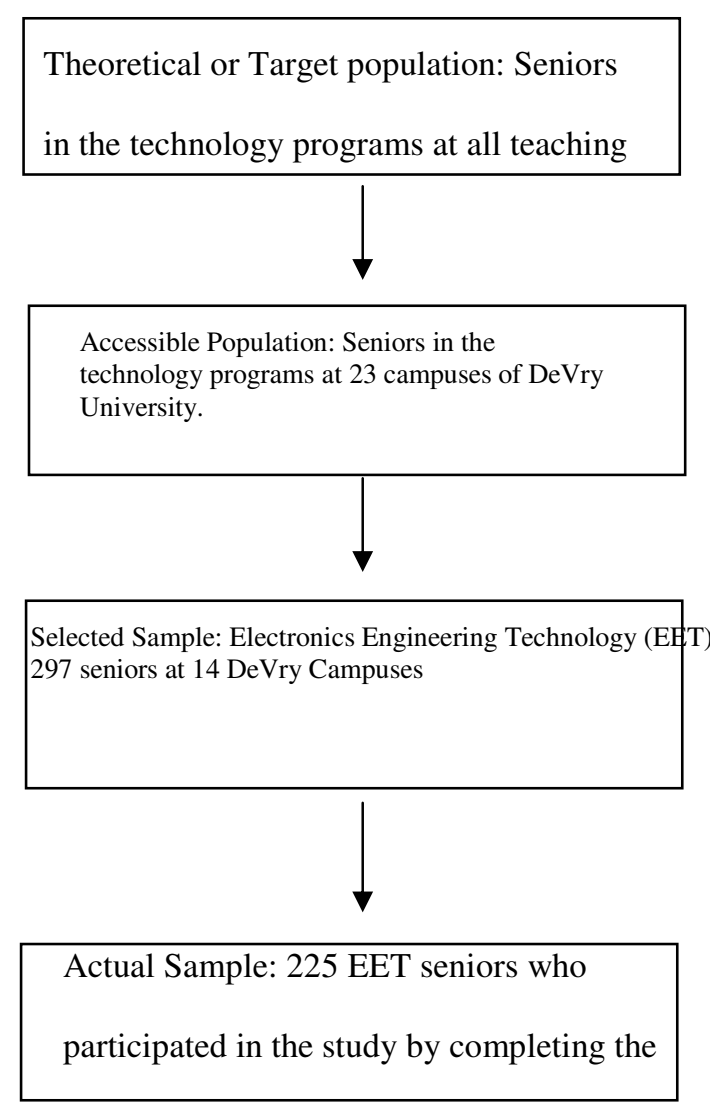

Figure 2. Sampling design for student survey. 


\section{SUMMARY OF RESULTS}

Table II presents a summary of results for students' perceptions of the importance of three faculty constructs for their self-reported learning/success. The highest level of agreement ( 90 percent or more) is revealed by four faculty sub-constructs: coordinating labs with lectures, up-to-date technical knowledge, organization and preparation for class and lab activities, and professors' lectures. Note that one of the faculty technical currency (FTC) and three of faculty teaching techniques (FTT), but none of the faculty commitment to student success (FCSS) items were among the sub-constructs that 90 percent or more of the students agreed were important for their learning/success.

\section{Table II}

Summary of Results: Highest and Lowest Levels of Agreement for Students' Perceptions of the Importance of The Faculty Constructs of Technical Currency, Teaching Techniques, and Commitment to Student Success.

\begin{tabular}{|c|c|c|c|}
\hline Sub-construct (Construct) & Agree & Mean & $\begin{array}{l}\text { Standard } \\
\text { Deviation }\end{array}$ \\
\hline \multicolumn{4}{|c|}{ Highest Level of Agreement ( $\geq 90 \%)$} \\
\hline Coordinating lab with lecture (FTT) & $91.9 \%$ & 6.10 & 1.16 \\
\hline \multicolumn{4}{|l|}{ Up-to-date technical knowledge (FTC) } \\
\hline & $91.4 \%$ & 5.90 & 1.16 \\
\hline $\begin{array}{l}\text { Organization and preparation for class and } \\
\text { lab activities (FTT) }\end{array}$ & $91.2 \%$ & 5.99 & 1.15 \\
\hline Professors' lectures (FTT) & $90 \%$ & 5.90 & 1.12 \\
\hline \multicolumn{4}{|c|}{ Lowest level of Agreement $(\leq 60)$} \\
\hline $\begin{array}{l}\text { Participation in technical seminars } \\
\text { /professional societies activities (FTC) }\end{array}$ & $57.4 \%$ & 4.75 & 1.48 \\
\hline $\begin{array}{l}\text { Publications/ technical papers/textbooks } \\
\text { (FTC) }\end{array}$ & $51.1 \%$ & 4.44 & 1.66 \\
\hline Use of group presentations (FTT) & $49.7 \%$ & 4.39 & 1.55 \\
\hline Use of PowerPoint (FTT) & $32.1 \%$ & 3.60 & 1.68 \\
\hline
\end{tabular}

And the lowest level of agreement (60 percent or less) is revealed by the faculty sub-constructs of participation in technical seminars /professional activities, publications/ technical papers/textbooks, use of group presentations, and use of PowerPoint. It is a very interesting to note that out of 20 faculty subconstructs, "how PowerPoint is used by the faculty", had the lowest level of agreement. This is especially surprising when one considers how often PowerPoint is used in academia for onsite and online (web based or web supported) classes whether for synchronous or asynchronous delivery modes. 
Table III presents a summary of strongest relationships ( $r \geq .30)$ between students' perceptions of the importance of faculty technical currency (FTC), faculty teaching techniques (FTT), and faculty commitment to student success (FCSS) and students' perceptions of learning/success expressed in terms of their self-reported technical competency (SRTC). The first dependent variable, critical thinking (STRC1) has two relationships of $r \geq .30$ with the independent variables: use of individual lab project of the summated faculty teaching techniques. The second dependent variable, job preparation (SRTC2), also has two relationships of $r \geq .30$ with the independent variables: summated faculty teaching techniques, and summated faculty commitment to student success. The third dependent variable, construction of a prototype (SRTC3) has six relationships of $r \geq$ .30 with the independent variables: computer software skills, use of individual lab projects, timely feedback on class and lab projects, summated faculty teaching techniques, high expectation of students, and summated faculty commitment to student success. And, the fourth dependent variable, summated self reported technical competency (SRTC), which is the sum of critical thinking, job preparation and construction of a prototype, has seven relationships of $r \geq .30$ with the independent variables, two with faculty technical currency constructs, two with faculty teaching techniques constructs, and three with faculty commitment to student success constructs. Only 1 relationship, out of 92 possible relationships between four dependent variables and 23 independent variables, was not statistically significant.

\section{Table III}

Summary of Results: Pearson Correlation Coefficients for the Relationship Between Students' Perceptions of the Importance of Faculty Technical Currency (FTC), Faculty Teaching Techniques (FTT), and Faculty Commitment to Student Success (FCSS) and Students' Perceptions of Learning/Success Expressed in Terms of Their Self-reported Technical Competency $(N=225)$

\begin{tabular}{|c|c|c|c|c|}
\hline $\begin{array}{l}\text { Faculty Sub-Construct } \\
\text { (Construct) }\end{array}$ & $\begin{array}{l}\text { Self-reported } \\
\text { technical } \\
\text { competency } \\
\text { (SRTC1) }\end{array}$ & $\begin{array}{l}\text { Self-reported } \\
\text { technical } \\
\text { competency } \\
\text { (SRTC2) }\end{array}$ & $\begin{array}{c}\text { Self-reported } \\
\text { technical } \\
\text { competency } \\
\text { (SRTC3) }\end{array}$ & $\begin{array}{l}\text { Summated } \\
\text { SRTC }\end{array}$ \\
\hline & $\begin{array}{c}\text { [Critical } \\
\text { Thinking] }\end{array}$ & $\begin{array}{c}\text { [Job } \\
\text { Preparation] }\end{array}$ & $\begin{array}{l}\text { [Construction } \\
\text { of a Prototype] }\end{array}$ & \\
\hline \multicolumn{5}{|l|}{$\begin{array}{l}\text { Statistically Most Significant } \\
\text { Relationships }(r \geq .30)\end{array}$} \\
\hline $\begin{array}{l}\text { Computer software skills } \\
\text { (FTC) }\end{array}$ & - & - & 0.31 & 0.30 \\
\hline Summated FTC construct & - & - & - & 0.30 \\
\hline Use of individual lab projects & 0.30 & - & 0.34 & 0.35 \\
\hline
\end{tabular}




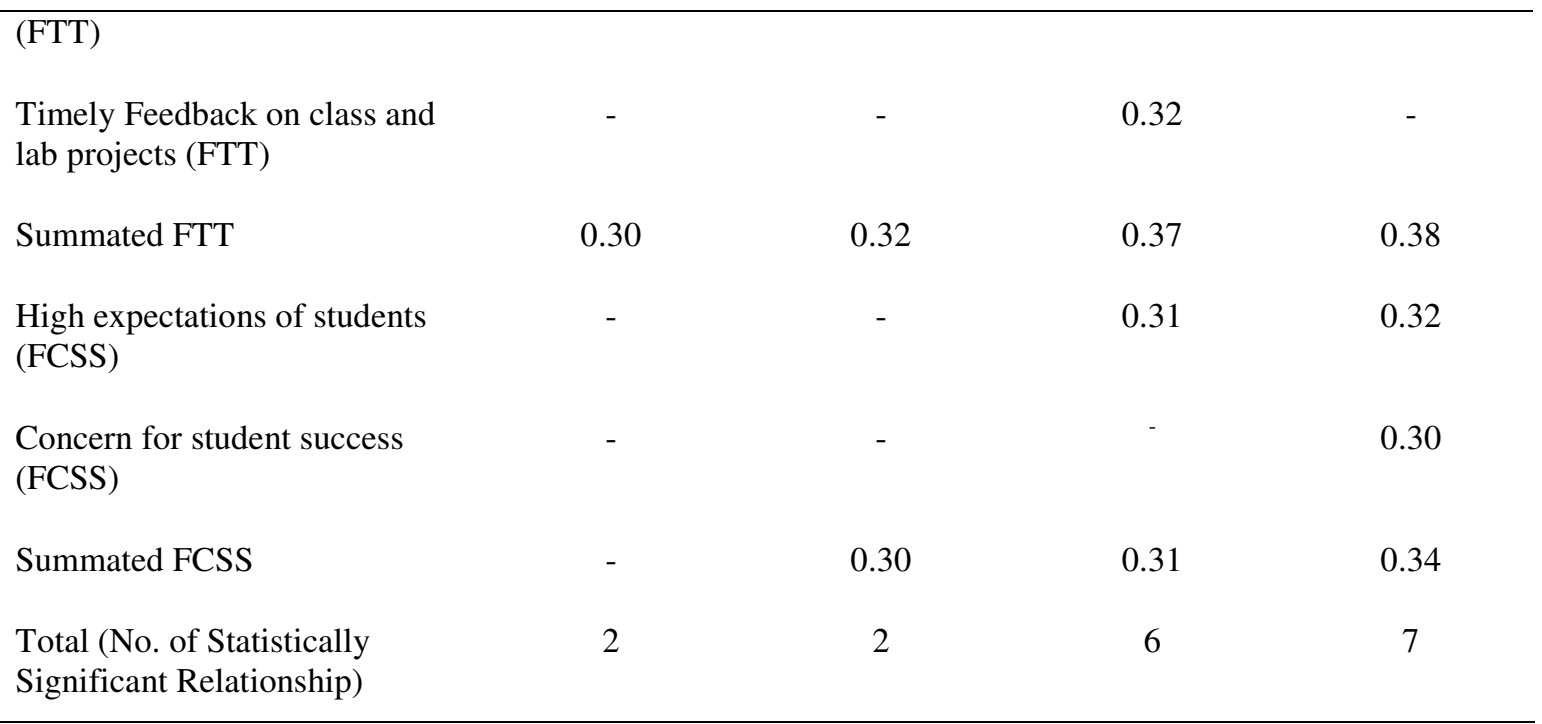

Note: For all listed correlations $p<0.001$ and the effect size is medium.

SRTC1: Given a technical challenge, a student can analyze a problem by thinking critically.

SRTC2: Student has confidence in his/her technical knowledge to be successful at an electronics

engineering technology (EET) job.

SRTC3: Given a technical problem or specification for a system design, a student can propose a solution by designing the necessary sub-system/circuits and by constructing a prototype of the system.

\section{Discussion of the Findings}

How do students perceive the importance of three faculty dimensions - technical currency, teaching techniques, commitment to student success for their learning and success? (Are means high or low?)

\section{Faculty Technical Currency (FTC)}

The analyses revealed that EET seniors perceive that the technical currency of faculty is important for their learning and success, as more than 80 percent of 225 EET seniors agreed that up-to-date technical knowledge, computer hardware and computer software skills, and knowledge of new and emerging technologies are important for their learning and success.

These results are significant when looked in light of the faculty technical currency study conducted by Khan et al. [2]. The study reported that more then 95 percent of faculty members surveyed agreed that technical currency of faculty is essential to make student learning more relevant. Further, 78 percent agreed that there exists a strong relationship between technical currency and student learning. The survey also revealed that only 26 percent of faculty members said that they have high-level skills in computer competency /IT/hardware area, and 49 percent reported that they have medium level skills in the software area. So there is a need for faculty to enhance their computer hardware and 
software skills, as the seniors perceive them to be important for their learning and success.

But only half of the EET seniors agreed that the faculty publications of technical papers and textbooks, and participation in technical seminar/professional societies activities are important to their learning/success. This low rate of agreement compared to other faculty technical constructs may be due to the fact that most students may not be aware of the role and process of publications and attending technical seminars/conferences and participating in the professional organization activities in the overall professional development of the faculty.

\section{Faculty Teaching Techniques (FTT)}

The analyses also revealed that the EET seniors consider that faculty teaching techniques is also important for their learning and success. About 80 percent agreed that a faculty pedagogical approach that incorporates use of a variety of teaching tools, use of a variety of teaching strategies, use of individual lab projects and timely feedback is important to their learning and success.

These results support Guskey's [3] findings that the teaching behavior of effective teachers incorporates providing regular and specific feedback to students about their learning. The results also agree with the recommendations (use of active learning techniques, providing feedback) made by Chickering and Gasmson [4] for effective undergraduate education.

More than 90 percent of seniors agreed that professor's lectures, coordinating lab with lecture, and organization and preparation for class and lab activities, are important for their learning and success. These results support the findings reported by Guskey regarding the importance of planning and organization. The majority of EET seniors perceive that coordinating lab with lecture is important for their learning. When a faculty member tries to coordinate lab with class, students see the application of technical theory and develop a clear understating of how to implement lab experiments/projects. This result appears to support one of Knowles [5] fundamental assumptions about instruction for adults: "Adults learn best when the subject content is clear and of immediate importance."

Only half of the respondents considered the use of group presentations important for their learning/success, and 42 percent disagreed with the importance of the use of PowerPoint for their learning and success. It appears that the majority of students perceive the use of PowerPoint as not important for their learning. This may be due to the fact that many faculty members just read their PowerPoint slides, making the presentation a monotonous and passive rather than an interactive exercise. So faculty members need to learn how to make PowerPoint presentations effective and interesting for students.

Out of 225 respondents, about 80 percent agreed that a faculty teaching approach which incorporates the use of a variety of teaching tools, use of a variety of teaching strategies, 
use of individual lab projects and timely feed back, is important to their learning and success.

These results support Guskey's [3] findings where he reported that the teaching behavior of effective teachers incorporates planning and organization, student participation, feedback about learning. The results also support the recommendations made by Caine and Caine [6] that teachers should incorporate a variety of experimental learning strategies in order to promote learning.

The students perceive that faculty teaching techniques is important for their learning/success. The importance of faculty pedagogy is also highlighted by considering the survey results reported by of Khan et al. [2]. Out of 226 faculty members surveyed, teaching in various technology-based programs all over the country, 47.3 percent said that they did not receive any training in the pedagogy. Therefore, there is a need for improving faculty pedagogy.

\section{Faculty Commitment to Student Success (FCSS)}

The study revealed that EET seniors perceive that faculty commitment to student success is important for their learning and success. About 80 percent of seniors agreed that the faculty commitment dimensions of dedication to students, being approachable, providing encouragement towards student accomplishment are important to their success and learning. Further, more than 75 percent of seniors agreed that professor's high expectations and concern for student success are important for their learning/success.

These results support Guskey's [3] findings about the teaching behavior of effective teachers. Guskey found that effective teachers have a positive regard for students and encourage student participation. 


\title{
Study-II: Assimilation and Learning to Teach at a For-Profit (non- traditional) Institution of Higher Education
}

\begin{abstract}
"The idea of not being here...not coming to work everyday, not teaching... that doesn't sound like anything I ever want to do...I've always liked it here, and while there have been challenges, especially with some of the changes that have been going on lately with the new stuff... on the whole I still love DeVry and am thankful that I've had the opportunity, especially after being out of education for so long... Now that I've gotten back into it, I never want to be out of it again... I can't think of anything more important to do."
\end{abstract}

--Mark, DeVry/Chicago

\section{Introduction}

This qualitative study focuses on the experience of faculty who teach at for-profit, postsecondary institutions. The purpose of this study is to increase our understanding of how faculty learn to teach, what they think about teaching, and how they experience teaching in the particular context of a for-profit, vocational-oriented institution of higher education. In the past decade, the landscape of higher education has changed greatly, and although recent studies have examined the non-traditional student, few studies are concerned with the faculty teaching experience of non-traditional institutions of higher education.

This qualitative study, utilizing a narrative case study approach (Denzin \& Lincoln 2002; Merriam 2001; Lyons \& LaBoskey 2002), focuses on the significance of discourse, context, and assumes the social construction of the participants' realities (Kempner \& Tierney, 1996), to make meaning of and understand the issue of quality education, at forprofit, non-traditional institutions.

Given the complexity surrounding the topic of teacher effectiveness, preparation, and evaluation, this qualitative study, utilizing a narrative case study approach, focuses on experiences of faculty who teach at for-profit institutions. The narrative design reveals these teachers' worldviews, their values, and their meaning-making systems. These views are important to the realm of higher education, as these faculty members may not have been socialized in the traditional culture. Furthermore, faculty need to be understood in their own terms in order to address future training and professional development needs. This research has implications for for-profit university faculty who want to improve their teaching effectiveness. Additionally, the research has implications for the for-profit institutions of higher education themselves, as well as on the students enrolled in these institutions of higher learning. Finally, given the changing faculty composition on the campuses of America's universities and colleges, this research has implications for traditional institutions of higher education. 


\section{Purpose of the Study}

As stated, the purpose of the study was to examine the conditions relating to teacher preparation and how they influence teacher effectiveness at DeVry University. This qualitative study, using the narrative case study approach, focuses on teaching practices and preparation at the Chicago campus of DeVry University, a for-profit institution of higher education

This study has implications for all for-profit university faculty and administrators, who serve undergraduate, career-oriented students. The knowledge elicited from the perceptions and experiences of these instructors has implications to the future success of the teachers and achievement for the students at for-profit universities.

\section{Research Questions}

The research questions for this study focused on the conditions and processes relating to the teaching experience of for-profit faculty and the lived experiences of these participants at for-profit universities. The following research questions directed my study:

1. What is the experience of faculty members who teach at a for-profit institutions of higher education?

2. How do they develop their approaches to and philosophies of teaching?

3. How do institutional structures, policies, and culture shape their understanding of their roles as faculty?

4. How do they construct an identity as faculty?

5. What are their processes of development as teachers?

\section{Participants and Sampling Design}

The primary sample for this case study included seven DeVry University faculty members from the Chicago campus. This sample included DeVry University instructors at the Chicago campus, based on selected criteria and significant issues related to forprofit institutions.

In order to assemble the seven participants, all DeVry University instructors at the Chicago campus were invited to participate in the study. This campus was selected based on three key issues: a varied background and differently prepared faculty, a diverse student population with specific learning needs, and a proximity to DeVry/DuPage, the campus at which I teach.

All faculty members from the Chicago campus were given the opportunity to become participants in the study. The ideal sample composition included a balanced mix of: 1) Full-time, technically-based faculty; 2) Full-time, general education faculty; 3) Part-time, technically-based faculty; and 4) Part-time, general education faculty. Upon selection for the study, the seven participants were then categorized in two groups based upon their years of service at DeVry University: Senior faculty participants and Junior faculty 
participants. This process of maximum variation sampling (Lincoln and Guba, 1985) allowed me, as the researcher, to discover dimensional range or variation of a concept and the relationship among concepts (Strauss and Corbin 1998). The maximum variation strategy promotes trustworthiness in the study because the method purposefully seeks "variation or diversity in sample selection to allow for a greater range of application of the findings by consumers of the research" (Merriam, 2002, p. 31).

\section{Data Collection}

Semistructured, in-depth, one-on-one interviews were the chief form for collecting data in my study, and several steps in this procedure were administered. First, interviewees were identified using purposeful sampling as indicated previously. Next, as discussed, the type of interview (semistructured, one-on-one interview) were employed as this format was the most pragmatic and allowed me to gather the most useful information to help answer the research questions I posed.

Three rounds of interviews were conducted with each of the seven selected participants, using the study's research questions to frame the interviews. In the first interview, questions related to the participant's background, including their childhood experiences and how their education may have affected their current position, further educational experiences, employment experiences, and life experiences. In the second interview, more focused attention was based on the participant's experience at DeVry University including their approaches to and philosophies of teaching and learning, understanding their roles as faculty, how they may have constructed their identity as faculty, and their process of development as a teacher. The third interview, often less formal than the first two interviews, was utilized for follow-up or clarifying questions for five of the seven participants, once the first two interviews had been conducted and analyzed.

\section{Data Analysis}

The data analysis for my narrative case study utilized the methodology of constant comparative analysis in order to code data. Prior to completing the constant comparative analysis process however, data was managed by creating and organizing files for the data. Furthermore, interviews were transcribed over a four month period.

Since narrative analysis combines a focus on a participant's actual story with some form of analysis of the social character of that story and that story is being told to an audience (the interviewer), the narration became interactional (Riessman, 1993). Additionally, since narratives frame a story and typically have a beginning, middle, end and a pointan answer to the question "so what?"-I looked across narratives to examine and analyze emerging themes or concepts through the use of participants' language and word patterns. The form and content of a participant's story must be socially recognizable if it is to be meaningful (Riessman, 1993).

\section{Summary of Findings}

Based upon the interviews conducted and the analysis of the data, participants shared similarities of how they view and interpret their institution and its mission. Participants 
also identified the diverse nature of the student population at DeVry/Chicago, students' specific learning needs, and which approaches and teaching methods work best to connect with the students at their campus. More specifically, DeVry faculty recognize their students to be desperate and struggling individuals, who lack outside support systems which could aid in their academic and personal success. Additionally, faculty view their students as being culturally diverse, exhibiting a variety of modes which indicate how they socialize, behave, and make meaning of their environment. DeVry faculty also perceive their students to be academically unprepared when they enter the classroom; however, faculty indicate their students approach education with high motivation levels and are willing to commit to learning as they realize education is the key to their future success.

Themes have emerged which demonstrate the participants' life stories. Parental expectations and career trajectories shaped the participants' lives. The participants discussed perceptions of how parental expectations influenced them to enter the field of education and later to become teachers. Participants also conveyed perceptions of how their career trajectories, or career paths, have led them to become faculty at DeVry/Chicago. Participants highlighted their educational experiences and how these experiences shaped their lives as teachers, and how field-based experiences, including administrative experiences within higher education, shaped how they view the DeVry University organization and its philosophies and policies today. Other participants held field-based positions completely outside the realm of education. These positions include working in the electronics or computer fields; one participant sold vacuum cleaners doorto-door. Participants also expressed their notions of how they became DeVry faculty; some participants expected to enter the field, while others did so unexpectedly, as they "fell into teaching."

Participants reflected upon teaching and their "teacher education," and they also perceived their "teacher education" to have transpired through one of two approaches: a formal approach or an informal approach. Participants, who learned to teach through a formal approach, enrolled in and attended college to learn to become a teacher and then earned teacher certification; participants, who learned to teach through an informal approach, detailed significant experiences related to teaching others, including other college students, friends, or siblings they may have tutored during their formative years. Participants perceived these experiences to be influential in their development as future teachers, and these experiences often served as their initial teacher training.

Participants' reflections on teaching also revealed their perceptions of effective and ineffective attributes of teachers and their methods and modes of delivery. Participants also reflected upon how these attributes translate into the educational philosophies they have adopted with their teaching at DeVry/Chicago.

The purpose and general nature of this study was to examine how participants, seven faculty members at DeVry/Chicago, perceive the institution, culture, and mission where they teach and how they viewed DeVry learners and their specific needs. This study examined how participants perceive how they were influenced to become teachers and 
how their career trajectory led them into the field of education. Participants reflected on teaching as well, including their perceptions of how they learned to teach, how they view effective teaching, and how these effective teaching ideas translate into their educational philosophy.

\section{Discussion of Findings}

Because the curricula at DeVry University focuses on distinct subject matter, particularly technological-based subject matter, employers feel students are ready to be placed within their organization immediately upon graduation. Graduates of for-profit institutions typically have learned field-based concepts and theories, and with a thorough knowledge base within their specific program of study, are effectively prepared to enter business and industry. Additionally, with hands-on experience, along with valuable internships and externships, for-profit graduates are equipped and able to begin their planned career. For-profit institutions fill this particular need within higher education as they provide the tools necessary to aid their students in learning a vocation and preparing for future careers.

The next significant question, then, is why does it matter that for-profit institutions fill a niche within higher education? As the landscape of higher education continues to change and evolve, it matters because for-profit institutions, and DeVry University specifically, offers an education to those who may otherwise not have been granted an opportunity. DeVry University affords these students the opportunity to become productive members of society who have a real chance at employment success. If they flourish professionally, the likelihood of them attributing that success to their education increases, which translates into a deep appreciation for education and encouragement for future generations to educate themselves as well. This "border group," armed with a DeVry education, will now have a voice, an opportunity to help bridge the gap between the "haves" and the "have-nots".

Throughout this paper, I reflected on the findings with regard to my original dissertation research questions relating to the experience of faculty members who teach at for-profit institutions of higher education, how they develop their approaches and philosophies of teaching, and how institutional structures, policies, and culture shape their understanding of their role as faculty. Additionally, I considered how DeVry/Chicago faculty construct an identity as faculty and what are their processes of development as teachers.

The answers to my original research questions emerged within the findings of this narrative case study, which encompasses three interrelated themes: 1) Who are we?: The institution, its mission, and its students, their learning needs, and their differences within differences; 2) Life stories: Decisions to teach, parental expectations, and career trajectories; and 3) Reflections on teaching: Teacher education, perceptions of effective and ineffective teaching, and how methods translate into philosophy.

Although each participant in this study was raised in different regions of the United States and Europe and each of the seven participants discussed his/her influences and 
career trajectories as they pertain to their role as faculty at DeVry/Chicago, it was often as if I had spoken with seven people who came from one neighborhood despite their differences. Whether it was how they perceived their institution and its mission, how they viewed their students and their students' specific needs and issues, or how they explained how they learned to teach and who they are as teachers at DeVry/Chicago today, each participant willingly expounded on each topic. Their explanations and themes that emerged were inextricably interrelated. One could not exist without the other, and each was necessary for their endurance at the institution.

As I looked back over the themes within this study, I realized the significance of how the participants' discourse created this interrelationship. I also realized the importance of my study and how it pertains to the success and effectiveness of faculty at DeVry University. Though other studies exist relating to the purpose and mission of for-profit institutions of higher education, none were quite like my study. My initial need to discover the experiences of faculty who teach at for-profit institutions of higher education and how they develop their approaches and philosophies of teaching and learning, along with how institutional structures, policies, and culture shape their understanding of their roles as faculty, was now satisfied because of my investigation and my findings. By telling their stories, I became convinced the participants of the study collectively achieved one voice by sharing their experiences; at the same time though, that one voice consisted of seven different and complex perceptions.

As I reread transcripts from my interviews and listened to this newly emerging voice, another intriguing aspect of the study became evident to me. The emerging themes were interrelated and interconnected. An examination of this interrelationship and interconnectedness also revealed the development process that was common to the participants.

The participants in this study shared various similarities and differences in their teaching experience at DeVry/Chicago. It is my challenge to the participants of the study and faculty within for-profit and traditional colleges and universities today to celebrate these experiences and learn from the participants. I challenge every institution of higher education to listen to the voices of their faculty and provide support programs and professional development opportunities, which recognize their background and experiences and enable them to become better teachers. If these challenges are met, then the experiences of the participants in this study will not go in vain. Rather, they can be applied to future faculty members as they endeavor to learn to teach because as George Bernard Shaw once wrote, "to me, the sole hope of human salvation lies in teaching." 


\section{Study-III: Prediction of Persistence at a Commuter Institution of Higher Education: A Multivariate Analysis of a Theoretical Model}

\section{Introduction}

Understanding and explaining why students depart from college has intrigued scholars since the beginning of the 20th century. Unfortunately, what was true then continues to be a reality today: the majority of college students continue to depart rather than graduate from their initial institutions (ACT, Inc., 2003). Although sophisticated theoretical models of departure have been constructed over this time period, there is still much to learn about the complex causes of student persistence. As student populations become more diverse and society continues to put substantial value on obtaining a college degree, it is critical to look into the academic and social communities of institutions of higher education.

\section{Literature Review}

Integration into the social and academic communities continues to play a central role in student success and persistence. Tinto (1987) stressed the importance of integration into these communities showing the more integrated, the more likely that student is to persist.

\section{The Academic Environment}

Academic integration has been defined as students' perception of their academic development. Or, said differently, their estimation of how they think they are advancing academically (Tinto, 1987).

\section{Academic Grade Point Average}

Pascarella and Terenzini (1991) posited that strong academic performance is an indicator of "successful adaptation to an academic environment"(p. 388). The persistence literature continues to yield compelling results supporting the relationship of strong academic performance with student persistence (Astin, 1993; Bean, 1990; Chen \& Thomas, 2001; Ishitani \& DesJardins, 2002; Lenning et al., 1980; Tinto, 1975).

\section{Faculty-student formal interaction}

The importance of effective faculty-student relationships reaches back to one's preschool experience. Patten (2001) detailed the importance of teacher-child relationships to the further success of the student. This relationship continues to be recognized as important at the college level. A large collection of literature exists that supports the principle that faculty interaction with students enhances academic integration (Bean, 1986; Lenning, 1982; NSSE, 2000; Pascarella, 1982; Tinto, 1987, 1997). Tinto noted that the frequency and quality of the interactions are central in determining persistence and commitment to the institution. Chickering and Gamson (1987) revealed student-faculty contact is the most important factor in student motivation and involvement. "Knowing a few faculty members well enhances students' intellectual commitment and encourages them to think about their own values and future plans" (II 13). Faculty can be liaisons to the rest of the institution; they have the ability to connect students with other facets of the institution- 
advising, student services, academic groups, and financial aid (Toy, 1985). Braxton, Milem, and Sullivan (2000) noted that teaching practices also play a significant role in student departure. They advocated that institutions should focus on efforts to improve pedagogy for faculty to both reduce retention and improve learning outcomes.

\section{The Social Environment}

Social integration pertains to the degree of congruency between the student and the social system of a college or university. Therefore, social integration and involvement in life outside of the classroom becomes central to explaining student persistence (Beal \& Noel, 1980; Gerdes \& Mallinckrodt, 1994; Hossler et al., 1990; Lenning et al. 1980; Pascarella, 1982; Spady, 1970; Tinto, 1975).

\section{Campus life}

The time students spend outside of the classroom plays an important role in a student's overall college experience (Kuh et al., 1991). A typical college student spends

approximately two thirds of their time in activities other than attending class and studying (Kuh et al.) Bean (1990) stated "when a variety of programs are offered to meet the needs of different types of students who provide meaningful involvement for students, faculty, and staff which focus on changing student attitudes are most likely to improve retention" (p. 156).

\section{Faculty-student informal interaction}

Students interact with many different individuals or what Pascarella (1980) referred to as "agents of socialization" outside of the classroom. As previously indicated, faculty interaction is an important factor in promoting academic integration. However, this interaction also affects the degree in which students integrate in the social climate of the institution. Informal contact with faculty, especially out-of-classroom contact with students, increases a student's probability to succeed (Bean, 1986; Terenzini \& Pascarella, 1994). Faculty members are allocating their time to research and teaching, leaving little time for out-of-class contact. Across all institutions faculty members were spending significantly less time advising and counseling students (Milem, Berger, \& Dey, 1997). Laden, Milem, and Crowson (2000) revealed that, "while contact is emerging as importantly strategic in student retention, it could well be losing power as an institutionalized characteristic of higher education" (p. 250). Terenzini and Pascarella (1994) believed that "instruction must be understood more broadly to include the important teaching that faculty do both inside and outside their classrooms" (II 30).

\section{Data Design and Analysis}

To investigate associations with social/academic variables and student success, data were collected in a three-step process over a 5-year period; 1999 (Year 1); 2000 (Year 2); and 2004 (Year 5). A longitudinal panel was established consisting of Year 1 student satisfaction data (see Tables 1.1 and 1.2) for all 4,571 students. The student cohort was measured for a second time the following year (2000, Year 2, N=697). Finally the student cohort was measured a third and final time after the fall term of 2004 showing whether the student graduated or departed. 
Table 1.1

Definitions and Measures of Interactional Determinants and Variables

\begin{tabular}{|c|c|c|c|}
\hline Variables & Definitions and measures & Source & Survey item(s) and values \\
\hline $\begin{array}{l}\text { Interactional } \\
\text { variables }\end{array}$ & $\begin{array}{l}\text { Interactional variables become a } \\
\text { major focus of student retention } \\
\text { because of the complex } \\
\text { relationships that transpire } \\
\text { between students and their } \\
\text { institution. }\end{array}$ & & \\
\hline Social variables & $\begin{array}{l}\text { Social Integration/Involvement. } \\
\text { The degree in which the student } \\
\text { participates or is integrated into } \\
\text { the social environment of the } \\
\text { institution. }\end{array}$ & & \\
\hline Campus life & $\begin{array}{l}\text { The degree to which the student } \\
\text { is involved and satisfied with } \\
\text { campus life. }\end{array}$ & SSI & $\begin{array}{l}\text { Composite of four SSI items, } \\
\text { scored on a scale of } 1 \text { to } 7 \\
1=\text { not satisfied at all } \\
7 \text { = very satisfied } \\
\text { 1. I can easily get involved in } \\
\text { campus organizations. } \\
\text { 2. The student center (commons) is } \\
\text { a comfortable place for students } \\
\text { to spend their leisure time. } \\
\text { 3. Student activity fees are put to } \\
\text { good use. } \\
\text { 4. The student handbook provides } \\
\text { helpful information. }\end{array}$ \\
\hline $\begin{array}{l}\text { Faculty } \\
\text { student } \\
\text { informal } \\
\text { interaction }\end{array}$ & $\begin{array}{l}\text { The amount and quality of } \\
\text { informal contact with faculty. } \\
\text { Justification for measures used } \\
\text { for social integration based on } \\
\text { Braxton and Brier (1989), } \\
\text { Pascarella et al. (1983), and } \\
\text { Pascarella \& Terenzini (1983) } \\
\text { where quality and impact and } \\
\text { quality of non-classroom } \\
\text { interactions were assigned to } \\
\text { social integration. }\end{array}$ & SSI & $\begin{array}{l}\text { Composite of three SSI items, } \\
\text { scored on a scale of } 1 \text { to } 7 \\
1=\text { not satisfied at all } \\
7=\text { very satisfied } \\
\text { 1. Faculty care about me as an } \\
\text { individual. } \\
\text { 2. Faculty are fair and unbiased in } \\
\text { treatment of individual students. } \\
\text { 3. Faculty are usually available } \\
\text { after class and during office } \\
\text { hours. }\end{array}$ \\
\hline
\end{tabular}

Note: SSI = Student Satisfaction Inventory. 
Table 1.2

Definitions and Measures of Academic Interactional Determinants and Variables

\begin{tabular}{|c|c|c|c|}
\hline \multirow{2}{*}{$\begin{array}{l}\text { Variables } \\
\text { Academic } \\
\text { variables }\end{array}$} & Definitions and measures & Source & Survey item(s) and values \\
\hline & $\begin{array}{l}\text { The degree in which the student } \\
\text { participates or is integrated into } \\
\text { the academic community of the } \\
\text { institution.. }\end{array}$ & & \\
\hline $\begin{array}{l}\text { Academic } \\
\text { GPA }\end{array}$ & $\begin{array}{l}\text { The degree to which the student } \\
\text { performs academically }\end{array}$ & SR & Student GPA \\
\hline $\begin{array}{l}\text { Academic } \\
\text { development }\end{array}$ & $\begin{array}{l}\text { Measures assigned to this } \\
\text { construct were based on the } \\
\text { researchers best interpretation } \\
\text { of what Tinto (1975) and } \\
\text { Pascarella and Terenzini (1983) } \\
\text { defined as "intellectual } \\
\text { development" in addition to } \\
\text { what Braxton and Brier (1989) } \\
\text { described as "academic } \\
\text { development." }\end{array}$ & SSI & $\begin{array}{l}\text { Composite of five SSI items, } \\
\text { scored on a scale of } 1 \text { to } 7 \\
1=\text { not satisfied at all } \\
7=\text { very satisfied } \\
\text { 1. I am able to experience } \\
\text { intellectual growth here. } \\
\text { 2. The content of the courses } \\
\text { within my major is valuable. } \\
\text { 3. Computer labs are adequate and } \\
\text { accessible. } \\
\text { 4. Major requirements are clear } \\
\text { and reasonable. } \\
\text { 5. There is a good variety of } \\
\text { classes provided on campus. }\end{array}$ \\
\hline $\begin{array}{l}\text { Faculty } \\
\text { student } \\
\text { formal } \\
\text { interaction }\end{array}$ & $\begin{array}{l}\text { The level and quality of } \\
\text { interaction between students } \\
\text { and faculty members. } \\
\text { Justification for measures of } \\
\text { academic integration based on } \\
\text { Pascarella et al. (1983) study } \\
\text { that was conducted at a } \\
\text { commuter institution as well as } \\
\text { Pascarella and Terenzini } \\
\text { (1983). Questions centered } \\
\text { around faculty concern for } \\
\text { teaching and the individual in a } \\
\text { classroom setting are included } \\
\text { in the composite. }\end{array}$ & SSI & $\begin{array}{l}\text { Composite of six SSI items, scored } \\
\text { on a scale of } 1 \text { to } 7 \\
1=\text { not satisfied at all } \\
7=\text { very satisfied } \\
\text { 1. The instruction in my major } \\
\text { field is excellent. } \\
\text { 2. The quality of instruction I } \\
\text { receive in most of my classes is } \\
\text { excellent. } \\
\text { 3. Adjunct faculty are competent } \\
\text { as classroom instructors. } \\
\text { 4. Nearly all faculty are } \\
\text { knowledgeable in their field } \\
\text { 5. Faculty take into consideration } \\
\text { student differences as they } \\
\text { teach. } \\
\text { 6. Faculty provide timely feedback } \\
\text { about student progress in a } \\
\text { course. }\end{array}$ \\
\hline
\end{tabular}

Note $:$ SSI = Student Satisfaction Inventory, $\mathrm{SR}=$ Student Records, GPA = Grade Point Average. 


\section{Differences in Persistence to Year 2 and Graduation Status}

Independent samples $t$ tests were employed to test for differences in persistence to Year 2 and graduation status. Out of the 4,571 students who started the study during Year 1, $70 \%(N=3,213)$ were still enrolled during Year 2, with $30 \%(N=1,358)$ dropping out. This finding is consistent with existing research of freshman year persistence identifying that on average, approximately one-third of entering freshman leave that institution one year later (ACT, 2003; Beal \& Noel, 1980; Levitz \& Noel, 1989; Tinto, 1993). Overall, students who persisted to Year 2 were more satisfied with their academic and classroom relationships with faculty members and possessed much higher GPA (see Table 1.3). Differences were also analyzed for the student cohort that persisted to Year $2(\mathrm{~N}=697)$ and whether the student graduated or not (see Table 1.4).

Table 1.3 Results of t Test Comparisons of Students Who Persisted to Year 2 Versus Those Who Dropped Out before Year 2

\begin{tabular}{|c|c|c|c|c|c|c|}
\hline \multirow[b]{2}{*}{ Model constructs } & \multicolumn{2}{|c|}{$\begin{array}{c}\text { Persisted to Year } \\
2 \\
(n=3,213) \\
\end{array}$} & \multicolumn{2}{|c|}{$\begin{array}{c}\text { Dropped out before } \\
\text { Year } 2 \\
(n=1,358)\end{array}$} & \multirow[b]{2}{*}{$t$} & \multirow[b]{2}{*}{$P$} \\
\hline & $M$ & $S D$ & $M$ & $S D$ & & \\
\hline Campus life & 4.96 & 1.13 & 4.94 & 1.19 & 0.30 & .77 \\
\hline $\begin{array}{l}\text { Faculty-student } \\
\text { informal } \\
\text { interaction }\end{array}$ & 5.35 & 1.02 & 5.29 & 1.12 & $2.00^{\mathrm{a}}$ & .05 \\
\hline $\begin{array}{l}\text { Academic } \\
\text { development }\end{array}$ & 5.56 & 0.93 & 5.49 & $1.0(2$ & $2.43^{\mathrm{a}}$ & .02 \\
\hline $\begin{array}{l}\text { Faculty-student } \\
\text { formal interaction }\end{array}$ & 5.37 & 1.02 & 5.24 & 1.13 & $3.80^{\mathrm{a}}$ & $<.001^{*}$ \\
\hline Academic GPA & 3.09 & 0.67 & 2.07 & 1.16 & $27.68^{\mathrm{a}}$ & $<.001^{*}$ \\
\hline
\end{tabular}

${ }^{a}$ Levene's $F$ was statistically significant $(p<.003)$, so the "equal variances not assumed" $t$ was used.

* Statistically significant after Bonferroni correction.

Table 1.4 Results of t Test Comparisons of Graduation for Students Who Persisted to Year

\begin{tabular}{|c|c|c|c|c|c|c|}
\hline \multirow[b]{2}{*}{ Model constructs } & \multicolumn{2}{|c|}{$\begin{array}{l}\text { Not graduated } \\
\quad(n=220)\end{array}$} & \multicolumn{2}{|c|}{$\begin{array}{l}\text { Graduated } \\
(n=467)\end{array}$} & \multirow[b]{2}{*}{$t$} & \multirow[b]{2}{*}{$P$} \\
\hline & $M$ & $S D$ & $M$ & $S D$ & & \\
\hline Campus life & 4.72 & 1.25 & 4.63 & 1.16 & 0.99 & .32 \\
\hline $\begin{array}{l}\text { Faculty-student } \\
\quad \text { informal } \\
\text { interaction }\end{array}$ & 5.09 & 1.21 & 4.98 & 1.14 & 1.23 & .22 \\
\hline $\begin{array}{l}\text { Academic } \\
\text { development }\end{array}$ & 5.29 & 1.11 & 5.19 & 1.06 & 1.23 & .22 \\
\hline $\begin{array}{l}\text { Faculty-student } \\
\text { formal interaction }\end{array}$ & 5.00 & $\begin{array}{l}1.20 \\
070\end{array}$ & $\begin{array}{l}4.95 \\
3.31\end{array}$ & $\begin{array}{l}1.23 \\
048\end{array}$ & $\begin{array}{r}0.47 \\
-10.01^{*}\end{array}$ & .64 \\
\hline
\end{tabular}


A paired $t$ test investigated differences between the same 697 students who had data for both Year 1 and Year 2 on the Student Satisfaction Inventory (SSI) to examine changes over time in student satisfaction scores. Overall, on every construct, satisfaction levels were lower for Year 2 than for Year 1. These were significant differences and demonstrated that students' satisfaction levels decrease as they move from their first to second year in college. Furthermore an analysis of effect sizes concluded that all of these differences were medium to large. These findings support what Wilder (1993) referred to as the sophomore slump.

Table 1.5 Results of t Tests on Differences in Student Responses to the Student Satisfaction Inventory from the Students in Year 1 and the Same Students in Year 2

\begin{tabular}{|c|c|c|c|c|c|c|}
\hline \multirow[b]{2}{*}{ Model constructs } & \multicolumn{2}{|c|}{$\begin{array}{c}\text { Year 1 } \\
\text { satisfaction } \\
(n=697)\end{array}$} & \multicolumn{2}{|c|}{$\begin{array}{c}\text { Year 2 } \\
\text { satisfaction } \\
(n=697)\end{array}$} & \multirow[b]{2}{*}{$t$} & \multirow[b]{2}{*}{$P$} \\
\hline & $M$ & $S D$ & $M$ & $S D$ & & \\
\hline Campus life & 5.02 & 1.14 & 4.68 & 1.18 & -7.38 & $<.001^{*}$ \\
\hline $\begin{array}{l}\text { Faculty-student } \\
\text { informal } \\
\text { interaction }\end{array}$ & 5.42 & 1.04 & 5.02 & 1.16 & -9.11 & $<.001^{*}$ \\
\hline $\begin{array}{l}\text { Academic } \\
\text { development }\end{array}$ & 5.63 & 0.92 & 5.23 & 1.07 & -9.90 & $<.001^{*}$ \\
\hline $\begin{array}{l}\text { Faculty-student } \\
\text { formal interaction }\end{array}$ & 5.43 & 1.03 & 4.98 & 1.21 & -10.24 & $<.001^{*}$ \\
\hline
\end{tabular}

\section{Discussion}

Faculty-Student Formal Interactions

Students who persisted to Year 2 were also more satisfied with their in-classroom relationships with faculty members. Students who interact and form positive academic/formal relationships with faculty members were more likely to persist and/or to continue their academic career (Astin, 1975, 1993; Beal \& Noel, 1980; Bean, 1986; Braxton et al., 2000; Hossler \& Bean, 1990; Johnson, 1997; Tinto, 1987, 2000). This finding adds further support to the importance of the interactions that take place in the classroom. This result is especially important for commuter institutions, where the classroom may be the only opportunity for students to interact with faculty and peers.

\section{Academic GPA}

The strongest statistically significant difference between students who persisted to Year 2 as well as those students who were more likely to graduate within five years was the students GPA. Students who were still enrolled in Year 2 of the study had as much as one grade point higher $(M=3.09)$ than those students who dropped out $(M=2.07)$.

Furthermore, students who persisted to Year 2 and graduated 5 years later possessed a $G P A$ that was at least .50 grade point higher than those students who did not graduate. Chen and Thomas (2001) also found GPA to be a significant predictor of persistence for not only the first term but throughout a student's academic career. The literature as well as the results of this study shows compelling support for the relationship between strong 
academic performance and persistence (Astin, 1993; Bean, 1990; Chen \& Thomas, 2001; Ishitani \& DesJardins, 2002-2003; Lenning et al., 1980; Tinto, 1975).

\section{Student Satisfaction Over Time}

Overall, on every construct, satisfaction levels were lower for Year 2 than for Year 1. The means were then ranked per year to see if satisfaction levels per each category changed over the two years. Table 1.6 shows the means and rankings per each year.

Table 1.6 Comparison of Satisfaction Means $(N=697)$

\begin{tabular}{lclc}
\hline Year 1 satisfaction & $M$ & Year 2 satisfaction & $M$ \\
\hline Academic development & 5.63 & Academic development & 5.23 \\
Faculty-student formal interaction & 5.43 & Faculty-student formal interaction & 4.99 \\
Faculty-student informal interaction & 5.42 & Faculty-student informal interaction & 5.02 \\
Campus life & 5.02 & Campus life & 4.68
\end{tabular}

Results conclude that students tend to be most satisfied with factors associated with their academic environment and classroom experiences and least satisfied with personal services. Another worthy observation is that for both years these satisfaction scores are not high. The range of scores (4.56-5.6) represents an actual satisfaction rating of neutral to satisfied, with the majority of the ratings falling into the somewhat satisfied (5.0) category. This shows there is considerable room for improvement with these satisfaction scores.

\section{Implications for Practice}

Using the results of these three studies, there are implications for practice as well as recommendations for further study, specifically for higher education institutions.

The first study revealed that the majority students (90\% or more) perceive that the most important factors that contributed to their learning and success are: coordinating lab with the lecture (FTT), up-to-date technical knowledge (FTC), organization and reparation of class and lab activities (FTT), and professors' lectures (FTT).

In the domains of engineering technology, to narrow the gap between the state-ofcurricula and state-of- technology in the industry, faculty are required to revise curricula frequently and maintain their technical currency. To improve student learning/success they are also required to learn the pedagogy. This endeavor is very challenging, and requires institutional vision, planning, and allocation of appropriate resources.

The findings of the second study and the acceptance of the themes which emerged open implications for DeVry faculty and students as well as countless possibilities for further study. Because there was such a vast difference among participants in nativity, race, and age, further study should be conducted to determine if there would be an impact on the emergent themes. 
Likewise, in regard to gender and the participants' childhood background and environment within the second study, implications for further study should be examined. For example, in regard to gender, four participants were women; three participants were men. During the course of the interview process, gender issues arose. Therefore, it would be interesting to explore these issues in greater depth. To what degree were the teaching and learning experiences different for men and for women? Another intriguing aspect of the study to consider would be to examine differences among teachers who were raised in urban environments compared to those who were raised in suburban or even rural environments. Within the second study, there were noticeable differences among the participants in this regard. Could the environment where a teacher was raised and educated influence one's teaching and learning experiences?

Finally, two additional aspects for further study would be to examine differences experienced by faculty based on their discipline as well as the varying methods or approaches to teaching of the participants. For example, do technically based faculty experience teaching differently than non-technical faculty? Are there separate differences even among technical instructors? For example, do electronics faculty experience teaching differently than computer teachers, as the world of computers evolves alarmingly fast, almost daily? At any institution of higher education where technical degrees are offered, these questions may be worth examining. Lastly, are there differences among participants and their varying methods or approaches to teaching? As shown in the second study, participants exhibited a "sink or swim" or "hold my hand" philosophy in regards to teaching DeVry/Chicago students. To what degree were teaching and learning experiences different for those who employ the "sink or swim" methods of teaching and for those who utilize the "hold my hand" approaches to teaching? Does a less personal, stricter approach to students compared to a more personal, friendly approach to students create a different teaching and learning experience for faculty?

Differences among such factors as race, country of origin, gender, or environment may shape the study differently based on faculty members' belief systems, values, and assumptions. Embedded in the complexity of a study's determining factors, the findings of the study may be shaped differently. For example, questions for a future study relating to the issue of an instructor's nativity may note differences how parental influences and expectations shaped the education of the instructor or how the faculty member translates methods into educational philosophy may shape the findings differently. Employing different questions in a study based on different elements could potentially shape the researcher's findings considerably.

Whatever the direction for further inquiry into this topic, the results of the second study, at the very least, provide the "tip of the iceberg" for the exploration of a domain heretofore neglected and still in need of investigation. The second study provided a voice for for-profit faculty to be heard and a model that can be studied and applied at all institutions of higher education. 
The third study highlighted the fact that $G P A$ was an important variable in predicting student success. This should alert institutions to focus on efforts that assist students to succeed academically: (a) build and provide high quality, highly interactive, and appropriate academic environments; (b) provide opportunities for academic growth; (c) focus efforts on delivering high quality instruction in the classroom.

Another statistically significant and common finding throughout the study was the importance of faculty-student relationships, both in and outside of the classroom. Faculty should be concerned about students' cognitive and social development. They should be devoting a large portion of their time to their students and other efforts to assist students to succeed. Faculty members have the ability to greatly influence students and should be utilizing that influence wisely. Systematic changes at the institutional level should take place that would provide environments and incentives that allow student-faculty relationships to be fostered (Milem et al., 2000). The findings of this study demonstrated that social variables significantly contributed student success. Sufficient resources should be devoted to this area providing opportunities for student involvement and input into decision making (such as student government or a student mentor program) appears to positively impact persistence. College should also be an enjoyable experience (Elliot, 2002). Institutions can look to implement appropriate social activities to make the students' experience more enjoyable.

Finally, the majority of satisfaction ratings fell into the "somewhat satisfied" category on the Student Satisfaction Inventory (SSI). Engage in activities that will improve satisfaction levels in these areas. Berger suggests (2001-2002) that students should have advocates and the opportunity to participate in organizational decision making. Faculty, staff, students, and administration should understand and assess the organizational environment on campus. Furthermore, for commuter institutions, interactions that occur in the classroom should be of particular importance-provide opportunities for growth and learning with academic and co-curricular programs (Braxton \& Mundy, 2001). Improvement in these satisfaction scores should lead to higher levels of student satisfaction and persistence rates.

\section{Conclusion}

The combination of these three studies reiterates the importance of quality in higher education. If student learning and success are to change for the better, we would all be better served by ensuring that quality is apparent in every facet of our institutions-high quality academic environments, high quality classrooms, and high quality social

programming. With devotion to quality we have our greatest chance to improve the state of higher education for all of our students now and our students of the future. 


\section{REFERENCES}

[1] Accreditation Board for Engineering and Technology (ABET). (2002). 2003-2004

Criteria for accrediting engineering technology programs. Baltimore, MD.

[2] Khan, A., Karim, A., Gloeckner, G., \& Morgan, G. (2004). Faculty technical currency: Status report on a national survey of engineering technology faculty. Paper presented at 2004 ASEE Annual Conference, June 20-23, Salt Lake City, UT, and published in the conference proceedings.

[3] Guskey, T. (1988). Improving student learning in college classrooms. Springfield,

IL: Charles Thomas Publisher.

[4] Chickering, A. W., \& Gamson, Z. F. (1987). Seven principles for good practice in undergraduate education. AAHE Bulletin, 39(7), 3-7.

[5] Knowles, M. S. (1980). The modern practice of adult education: From pedagogy to androgogy. Englewood Cliffs, NJ: Cambridge Adult Education.

[6] Caine, R. N., \& Caine, G. (1991). Making connections: Teaching and the human brain. Alexandria, VA: Association for Supervision and Curriculum Development.

[7] Denzin, N.K., and Lincoln, Y.S. (2002). Handbook of qualitative design. Second edition. Thousand Oaks, CA: Sage.

[8] Merriam, S.B. (2001). Qualitative research and case study applications in education. San Francisco: Jossey-Bass.

[9] Lyons, N. and LaBoskey, V.K. (2002). Narrative inquiry in practice: Advancing the knowledge of teaching. New York: Teachers College.

[10] Kempner, K., and Tierney, W.G. (1996). The social role of higher education: Comparative perspectives. New York: Garland.

[11] Lincoln, Y.S. and Guba, E.G. (1985). Naturalistic inquiry. Beverly Hills, CA: Sage.

[12] Strauss, A.L., and Corbin, J. (1998). Basics of qualitative research: Techniques and procedures for developing grounded theory. Thousand Oaks, CA: Sage.

[13] Strauss, A.L., and Corbin, J. (1998). Basics of qualitative research: Techniques and procedures for developing grounded theory. Thousand Oaks, CA: Sage.

[14] Riessman, C. (1993). Narrative analysis. Newbury Park, CA: Sage.

[15] ACT, Inc. (2003, June). National collegiate retention and persistence to degree rates. Retrieved January 20, 2005, from http://www.act.org/path/policy/pdf/

retain_2003.pdf

[16] Tinto, V. (1987). Leaving college: Rethinking the causes and cures of student attrition. Chicago: University of Chicago Press.

[17] Pascarella, E. T., \& Terenzini, P.T. (1991). How college affects students. San Francisco: JosseyBass.

[18] Astin, A. W. (1993). What matters in college: Four critical years revisited. San Francisco: JosseyBass. 
[19] Bean, J. P. (1990). Why students leave: Insights from research. In D. Hossler, J. P. Bean, \& Associates (Eds.), The strategic management of college enrollments (pp. 147-169). San Francisco: Jossey-Bass.

[20] Chen, S. S., \& Thomas, H. (2001). Constructing vocational and technical college student persistence model. Journal of Vocational Education Research, 26, 26-55.

[21] Ishitani, T. T., \& DesJardins, S. L. (2002-2003). A longitudinal investigation of dropout from college in the United States. Journal of College Student Retention: Research, Theory \& Practice, 4, 173-201.

[22] Lenning, O. T., Beal, P. E., \& Sauer, K. (1980). Retention and attrition: Evidence for action and research. Boulder, CO: National Center for Higher Education Management Systems, Inc.

[23] Tinto, V. (1975). Dropout from higher education: A theoretical synthesis of recent research. Review of Educational Research, 45, 89-125.

[24] Patten, P. (2001, March-April). The fourth 'R': Teacher-child relationships are central to quality. Parent News, 1-4.

[25] Bean, J. P. (1986). Assessing and reducing attrition. New Directions for Higher Education, 53, 4761.

[26] Lenning, O. T. (1982). Variable selection and measurement concerns. In E. T. Pascarella (Ed.), Studying student attrition (pp. 35-53). San Francisco: Jossey-Bass.

[27] National Survey on Student Engagement. (2000). National benchmarks of effective educational practice. Carnegie Foundation for the Advancement of Teaching and Learning and the Pew Forum on Undergraduate Learning.

[28] Pascarella, E. T. (1982). Concluding thoughts. In E. T. Pascarella (Ed.), Studying student attrition (New Directions for Institutional Research, No. 36, pp. 89-91). San Francisco: Jossey-Bass.

[29] Tinto, V. (1997). Classrooms as communities. Journal of Higher Education, 68, 599-623.

[30] Toy, T. J. (1985). Increasing faculty involvement in retention efforts. In U. Delworth \& G. R. Hanson (Eds.), Increasing student retention (pp. 383-401). San Francisco: Jossey-Bass.

[31] Braxton, J. M., Milem, J. F., \& Sullivan, A. S. (2000). The influence of active learning on the college student departure process. Journal of Higher Education, 71, 569-590.

[32] Gerdes, H., \& Mallinckrodt, B. (1994). Emotional, social, and academic adjustment of college students: A longitudinal study of retention. Journal of Counseling \& Development, 72, 281-288. Retrieved January 28, 2003 from http://newfirstsearch.oclc.org

[33] Hossler, D., Bean, J. P., \& Associates. (1990). The strategic management of college enrollments. San Francisco: Jossey-Bass.

[34] Beal, P. E., \& Noel, L. (1980). What works in student retention (The Report of a Joint Project of the American College Testing Program and the National Center for Higher Education Management). Iowa City, IA: American College Testing Program; Boulder, CO: National Center for Higher Education Management.

[35] Spady, W. (1971). Dropouts from higher education: Towards an empirical model. Interchange, 2, $38-62$. 
[36] Kuh, G. D., Schuh, J. H., Whitt, E. J., \& Associates. (1991). Involving colleges: Successful approaches to fostering student learning and development outside the classroom. San Francisco: Jossey-Bass.

[37] Pascarella, E. T. (1980). Student-faculty informal contact and college outcomes. Review of Educational Research, 50, 545-595.

[38] Terenzini, P. T., \& Pascarella, E.T. (1994). Living with myths: Undergraduate education in America. Change, 26, 28-32. Retrieved January 17, 2003, from http://www.newfirstsearch.oclc.org

[39] Milem, J. F., Berger, J. B., \& Dey, E. L. (2000). Faculty time allocation. Journal of Higher Education, 71, 454-475.

[40] Laden, B. V., Milem, J. F., \& Crowson, R. L. (2000). New institutional theory and student departure. In J. M. Braxton (Ed.), Reworking the student departure puzzle (pp. 235-256). Nashville, TN: Vanderbilt University Press.

[41] Braxton, J. M., \& Brier, E. M. (1989). Melding organizational and interactional theories of student attrition: A path analytic study. Review of Higher Education, 13, 47-61.

[42] Pascarella, E. T., \& Terenzini, P. T. (1983). Predicting voluntary freshman year persistence/withdrawal behavior in a residential university: A path analytic validation of Tinto's model. Journal of Educational Psychology, 75, 215-226

[43] Levitz, R., \& Noel, L. (1989). Connecting students to institutions: Keys to retention and success. In L. M. Upcraft \& J. N. Gardner (Eds.), The freshman year experience (pp. 65-81). San Francisco: Jossey-Bass.

[44] Tinto, V. (1993). Leaving college: Rethinking the causes and cures of student attrition (2nd ed.). Chicago: University of Chicago Press.

[45] Wilder, J. S. (1993). The sophomore slump: A complex developmental period that contributes to attrition. College Student Affairs Journal, 12, 18-27.

[46] Astin, A. W. (1975). Preventing students from dropping out. San Francisco: Jossey-Bass.

[47] Johnson, J. (1997). Commuter college students: What factors determine who will persist and who will drop out? College Student Journal, 6, 323.

[48] Tinto, V. (2000). Linking learning and leaving: Exploring the role of the college classroom in student departure. In Braxton, J. M. (Ed.), Reworking the student departure puzzle (pp. 81-94). Nashville, TN: Vanderbilt University Press.

[49] Elliot, K. M. (2002). Key determinants of student satisfaction. Journal of College Student Retention, 4, 271-279.

[50] Berger, J. B. (2001-2002). Understanding the organizational nature of student persistence: Empirically based recommendations for practice. Journal of College Student Retention: Research, Theory and Practice, 3, 3-21.

[51] Braxton, J. M., \& Mundy, M. E. (2001-2002). Powerful institutional levers to reduce college student departure. Journal of College Student Retention: Research, Theory and Practice, 3, $91-$ 118. 